\title{
O BRASIL E A REGULAMENTAÇÃO DOS INVESTIMENTOS ESTRAVGEIROS NA ORGANIZAÇÃOO MUNDIAL DO COMÉRCIO
}

\author{
I.eandro Rocha de Aruajjo \\ Mestrando em Direito Internacional pela \\ Faculdade de Dircito da Universidade de São \\ Paulo.
}

\begin{abstract}
Resumo:
A Organização Mundial do Comércio (OMC) assumiu papel de destaque no cenário internacional, principalmente no que se refere à regulamentação do comércio internacional. trazendo recentemente para sua estrutura normativa a regulamentação dos investimentos estrangeiros. $\mathrm{O}$ presente ensaio apresenta um estudo sobre a matéria na $\mathrm{OMC}$, bem como sobre as perspectivas de uma regulamentação que possibilite a promoção do desenvolvimento para uma grande variedade de países, tais como países em desenvolvimento como o Brasil.
\end{abstract}

Abstract:

The World Trade Organization (WTO) has assumed a prominent role in world's scenario. mainly referring to the world trade regulation, recently bringing to its legal structure the regulation of foreign investments. The present essay presents a study over this subject in WTO, as well as the perspectives of a regulation that enables the promotion of development to a large variety of countries, such as developing countries like Brazil.

Unitermos: Organização Mundial do Comércio (OMC); investimentos estrangeiros; regulamentação; desenvolvimento.

Keywords: The World Trade Organization (WTO); legal structure of the foreign investments.

1. Introdução.

A Organização Mundial do Comércio (OMC) ocupa, na atualidade, papel de destaque no rol das organizações internacionais em funcionamento, sendo considerada uma das mais importantes em virtude das funções desempenhadas, do objeto tratado em seu âmbito e das conscqüências econômicas advindas de suas deliberações e decisões.

Desde o início do século $\mathrm{XX}$, já se podia verificar a presença de uma preocupação em regulamentar o fluxo comercial internacional, sendo que com a crise 
de 1929, os mais diversos países adotaram o protecionismo de seus mercados como forma de superar o impacto econômico. Já em 1941, a Carta Atlântica estabeleceu a participação de todos os Estados no comércio internacional, afirmando ainda o compromisso europeu de erradicar as barreiras coloniais.

Em 1944, na Conferência de Bretton Woods, foram idealizados os pilares do sistema econômico-financeiro e comercial global. Assim, o Banco Internacional para Reconstrução e Desenvolvimento (BIRD) e o Fundo Monetário Internacional (FMI) foram criados, regulando o sistema econômico e financeiro. Todavia, a Organização Internacional do Comércio (OIC), que deveria regular o sistema comercial mundial, não obteve êxito, por divergências entre os EstadosMembros, principalmente os EUA.

Contudo, uma regulamentação mínima do comércio mundial se fazia necessária. Desse modo, para possibilitar esta regulamentação, foi criado, em 1947, um acordo sobre comércio e tarifas denominado GATT (General Agreement on Trade and Tariffs). A sua finalidade específica seria aumentar o intercâmbio entre os diversos paises-contratantes através de regras claras e comuns, evitando-se, assim, novas tensões e crises entre os diversos protagonistas e coadjuvantes no cenário internacional, situação que se perpetuou por quase todo o século XX.

Com o fim da Guerra Fria e a consagração da economia de mercado em esfera mundial, foram redefinidos os eixos de poder estruturados com base no pósguerra e predominantes até o final dos anos 80 . O planeta deixou de ser bipolarizado, dentro de uma perspectiva bélico-ideológica, para se tornar multipolarizado em um contexto econômico-comercial, com realce principal para os EUA, mas também com as presenças marcantes da União Européia e do bloco asiático, liderado pelo Japão, $\mathrm{em}$ que pese as recentes investidas bélicas unilaterais promovidas pelo eixo Washington-Londres.

Assim, a relevância desta recente organização internacional pode ser facilmente verificada através da análise da nova ordem mundial, que se apresenta para o início do século XXI. A principal função exercida pela $\mathrm{OMC}$ refere-se à regulação dos fluxos comerciais em relação a bens e serviços entre seus Estados-Membros, destacando-se a promoção da liberalização comercial como principio norteador, com a redução das barreiras incidentes sobre os produtos comercializados entre os diversos paises membros. Deve-se salientar que tais paises representam hoje a quase totalidade das nações existentes no globo. 
Nesta perspectiva de universalidade e regras definidas de comércio, é de grande interesse o tratamento conferido ao tema investimentos no âmbito da OMC, tanto para os paises desenvolvidos quanto para os países em desenvolvimento, em decorrência da importância outorgada às empresas transnacionais para o comércio mundial. Ressalte-se que elas negociaram, somente no ano de $1995,{ }^{1}$ entre suas subsidiárias, quase um terço dos US\$ 6.1 trilhões do comércio mundial de bens e serviços. Em virtude disso, são também denominadas representantes do "poder econômico privado" 2

Referidas empresas possuem, normalmente, sede em países desenvolvidos com atuação em todo o mundo, dispondo, às vezes, de capacidade financeira surpreendente se comparada ao PIB de alguns países. Na perspectiva dos investimentos, serão analisados os investimentos tanto na perspectiva de longo prazo, denominados investimentos estrangeiros diretos (FDI em inglês ${ }^{3}$ ), quanto na perspectiva de curto prazo, ou seja, os investimentos de portfólio, vez que a regulamentação de ambos está em discussão nas negociações do Grupo de Trabalho sobre Comércio e Investimentos da OMC.

Os investimentos estrangeiros diretos são definidos por Krugman como "fluxos internacionais de capital pelos quais uma empresa em um pais cria ou expancle uma filial em outro" "Esta forma de investimento é também chamada de longo prazo porque envolve não só uma transferência de recursos, mas também a aquisição do controle. Neste ponto, é de fundamental importância o papel das empresas transnacionais, ${ }^{5}$ pois a sua instalação nos diversos países ocasiona um enorme aporte de recursos, gerando empregos, receita e modernização tecnológica do país receptor dos investimentos.

I. "Beyond the agreements: investment, competition, procurement, simples procedures". Disponivel em: http://www.wto.org. Acesso em 07 agosto 2002.

2. FONSECA, J. B. L. Direito Fconômico. O destacado professor se refere a Poder Econômico Privado para estabelecer um paradoxo em relação ao Poder Económico Público, ou seja, o Fstado.

3. Há ainda para o mesmo termo a sigla em inglês FDI, que significa Foreign Direct Investment.

4. KRUGMAN \& OBSTFELD, Economia Internacional: Teoria e Politica, p. 175.

5. Segundo Roberto Luiz Silva. as empresas transnacionais são aquelas capazes de influenciar a economia de diversos paises ao exercerem neles a sua atividade, tendo seu poder de decisão disperso nas suas subsidiárias e atuando nos Estados hospedeiros como pessoa juridica de direito interno. Ver SII.VA. Direito Internacional Público, p. 388. 
Os investimentos de portfólio, por outro lado, são todos os investimentos nos quais o investidor não obtém uma influência duradoura sobre o gerenciamento do negócio. Normalmente eles são de curto prazo e englobam investimentos em ativos financeiros sem a expectativa de controle e gerenciamento dos ativos reais, nos quais os ativos financeiros estão baseados. ${ }^{6}$ Outros exemplos de investimento de portfólio incluem interesses em acordos de concessão, direitos contratuais (propriedade intelectual) e aplicações financeiras.

O presente ensaio se propõ a apresentar como foco de análisc as medidas relacionadas à regulamentação dos investimentos no seio da OMC, a fím de proporcionar uma visão crítico-social dos possiveis benefícios e malefícios, através de uma perspectiva do desenvolvimento, logrados na aprovação de um Acordo Geral sobre Investimentos.

Desse modo, apresentará o item 2 a forma como está estruturada a regulamentação dos investimentos no âmbito da Organização Mundial do Comércio, assim como as propostas de reforma do presente quadro. No item 3, serão estudadas a posição brasileira diante do tema e as implicações para o Brasil das novas propostas sugeridas no Grupo de Trabalho sobre Comércio e Investimentos. No item 4, será abordada uma perspectiva para o desenvolvimento no que se refere às negociações sobre investimentos na OMC. Por fïm, no item 5, será elaborada uma conclusão acerca da viabilidade em se atingir, para o tema, uma perspectiva sobre o desenvolvimento diante das negociações na OMC.

2. A regulamentação atual dos investimentos na OMC:

A regulamentação dos investimentos na esfera multilateral vem sendo estudada desde a Conferência de Brellon Woods, em 1944. na qual foram idealizados os pilares do sistema econômico-financeiro e comercial global. Todavia, por não ter a OIC obtido êxito, deixou o tema "investimentos" de ser regulamentado na esfera internacional de comércio, posto que na época somente fora aprovado o Acordo (jeral sobre Comércio e Tarifas - GATT, que se referia ao comércio de bens e redução de tarifas entre as Partes Contratantes.

6. Para tal definição, ver o documento WT/WGTI/W/I42, no site www.wto.org. 
Apenas durante a Rodada Uruguai (1986-1994), foi a regulamentação dos investimentos novamente colocada em negociação. Na adoção de uma regulamentação para este tema, destacou-se a contraposição existente entre os interesses dos países desenvolvidos e os dos países em desenvolvimento. Enquanto os primeiros empenharam-se na regulamentação das medidas relacionadas aos investimentos e, conseqüentemente, na limitação da atuação dos governos dos países em desenvolvimento sobre os investimentos estrangeiros, os segundos buscaram a manutenção de padrões mínimos de regulação dos investimentos estrangeiros, com a ampla liberdade de aplicação das TRIMs (Trade Related Investment Measures), ${ }^{7}$ como forma a possibilitar um desenvolvimento equilibrado em seu próprio mercado interno.

Desse modo, o enorme conflito de interesses gerado ocasionou grande impasse nas negociações sobre investimentos, tendo, ao fim da Rodada Uruguai, sido apenas estabelecido um Acordo sobre Medidas de Investimento Relacionadas ao Comércio - Acordo TRIMs. ${ }^{8}$ Este acordo teria por finalidade restringir as políticas dos Estados-Membros que violassem as regras da OMC, mais especificamente no que tange às regras do tratamento nacional e da proibição de restrições quantitativas aplicadas para os investimentos internacionais, ainda assim somente no que referissem ao comércio de bens.

Assim sendo, a imposição de novas TRIMs pelos países membros da OMC. inconsistentes com o art. III (tratamento nacional) e com o art. Xl (proibição das restrições quantitativas) do Acordo Geral do GATT, passaram a ser proibidas,?

7. As TRIMs são medidas aplicadas pelos diversos Estados, incidentes sobre os investimentos estrangeiros, com o fito de conformá-los ao interesse nacional e às necessidades locais. Ver RAINELLI, A Organização Mundial do Comércio, p. 61.

8. O Acordo Geral sobre Medidas de Investimento relacionadas ao Comércio - Acordo sobre TRIMs - foi introduzido no ordenamento juridico brasileiro pelo Decreto Presidencial n. 1.355, de 30.12.94 (Promulga a Ata Final que incorpora us resultados da Rodada Uruguai de Negociações Comerciais Vultilaterais do (jATT).

9. THORSTENSEN, OMC - Organização Mundial do Comércio: As regras do comércio internacional e a nova rodada de negociaçōes multilaterais, p. 102. Segundo a autora, "os desennolvidos propuseram negociações amplas sobre mediadus que afetavam ofluxo de investimentos, inclusive introduzindo os principios da Nação Mais Favorecida e de tratamento nacional para a área de investimentos. A posiçâo dos paises em desenvolvimento era de que o teina investimentos estava fora do GATT, mas que se fosse introduzido nas negociações deveria também incluir temas como as práticas das multinacionais que ajetam o comércio, como transferência de recursos via prȩ̣os, práticas comerciais restritivas e transferência de lecnologia. - efeitos restritivos e distorcivos uo comércio. Após grandes debates, as negocią̧öes ficaram restritas aos itens relacionados ao Artigo III do Acordo Geral relativos ao tratamento nacional, e ao Arligo XI, relativos à eliminação de restriçães quantitativas" 
pelo seu caráter restritivo do comércio, sendo que às existentes à época foram impostos termos finais para serem retiradas dos diversos ordenamentos jurídicos dos Estados-membros.

Tais medidas referentes aos investimentos e ligadas ao comércio eram vistas pelos países desenvolvidos como medidas que possuem efeitos restritivos e distorcivos ao comércio. ${ }^{10}$ Desse modo, deve-se ressaltar que o Acordo TRIMs acabou por diminuir os efeitos para o comércio internacional decorrentes da atuação dos países em desenvolvimento, por condicionar a atuação estatal. Tal fator iniciou uma "liberalização dotada de proteção" do regime de investimentos para os investidores estrangeiros.

Por outro lado, segundo Rainelli," as TRIMS teriam também o "objetivo de limitar os efeitos negativos das implantações estrangeiras" para o comércio de bens, tais como a transferência de preço, a venda controlada, a fixação de preços e a repartição de mercado. ${ }^{12}$ Elas são, por outro lado, consideradas como instrumentos de politica econômica, aptas a promover o desenvolvimento, o que poderia se dar através da imposição de medidas como:

- regras de conteúdo local (que impõem uma percentagem mínima de componentes de origem local para um bem ser considerado como nacional e, portanto, isento de direitos aduaneiros);

- regras de equilibrio do comércio externo (que impõem uma cobertura das importações da firma por um dado volume de exportações) e;

- regras de observância mínima de exportações (certos países só autorizam a implantação de firmas estrangeiras se destinarem à exportação e não ao mercado local).

O referido Acordo TRIMs foi utilizado como parâmetro para a análise de medidas tomadas por alguns governos, consideradas distorcivas ao comércio, como as levadas ao Sistema de Solução de Controvérsias da OMC, que são as seguintes:

10. Segundo Michel Rainelli, as TRIMs podem contituir "nova forma de protecionismo, mesmo sendo dificeis de fazer respeitar". Ver RAINELLI, A Organização Mundial do Comércio, p. 61.

11. RAINELLI, Op. Cit., p. 62.

12. TROYANO. Medidas de investimento relacionadas ao comércio, p. 566. 
Comunidade Européia: ${ }^{13}$ regime para a importação, venda e distribuição de bananas;

- Indonésia: certas medidas relativas à indústria automobilística;

- Canadá: certas medidas relativas à indústria automotiva.

Todavia, ressalte-se que ao consagrar as regras do tratamento nacional e da proibição das restrições quantitativas, no que se refere ao comércio de bens, estabeleceu o referido acordo que não se enquadrando o investimento realizado nesta perspectiva, não estaria cle sujeito a qualquer regulamentação.

Em virtude da própria mudança do objeto do comércio internacional, que hoje inclui o amplo setor de serviços, bem como o de diversos tipos de investimentos, foi proposto, em 1996, durante a Conferência Ministerial de Cingapura, um estudo sobre a criação de um Acordo Geral sobre Investimentos (AGI), que regulamentasse de maneira ampla a questão. Desde então, foi instituído um Grupo de Trabalho sobre Comércio e Investimento para estudar e fazer proposições accrca do tema.

A Declaração Ministerial de Doha (2001) estabeleceu uma série de conceitos que deveriam ser trabalhados antes de se chegar a uma efetiva negociação. ${ }^{14}$ Assim, as negociações sobre o referido acordo somente se iniciarão após a V Conferência Ministerial, em Cancún (México). em setembro de 2003, sendo que na oportunidade será decidido pela incorporação ou-não ao single undertaking ${ }^{15}$ do tema relativo aos investimentos. ${ }^{16}$

13. Apesar de o membro da OMC ser atualmente a União Européia, à época da conclusão da negociação ainda não havia entrado em vigor o Tratado de Maastricht, que a criou (artigo $\mathrm{A}$ ). Assim, mesmo sendo partc a União Européia, foi mantida a denominação original, qual seja Comunidade Européia, para se referir a este membro. Dispõe o Tratado de Maastricht:

"Art. A. Pelo presente Tratado, as Altas Partes Contratantes instituem entre si uma União Européia, adiante designada por "União". (...) A União funda-se nas Comunidades Européias, completadas pelas politicas e formas de cooperação instituidas pelo presente Tratado. A União tem por missão organizar de forma coerente e solidária as relaçōes entre os Fstados-membros e entre os respectivos povos.

14. A Declaração Ministerial de Doha foi firmada na Conferência Ministerial realizada no Catar, em novembro de 2001. Ver site www.wto.org.

15. O "single underlaking" significa que nada estará acordado até que tudo esteja acordado entre os paises partes na negociação. Para esta definição. ver o site: www.dfait-maeci.gc.ca/dcc.tna-nac/wtogaz02.e.asp.

16. Além dos investimentos, farão parte da pauta de negociações os temas referentis à concorrência. facilitação e transparência em compras governamentais, entre outros. 
Conforme já dito anteriormente, a Declaração Ministerial de Doha17 conferiu a este Grupo de Trabalho poderes apenas para analisar c discutir os seguintes pontos centrais: alcance e definição do tema investimentos, transparência, nãodiscriminação. modalidades para pré-estabclecimento baseadas em listas positivas do tipo GATS (Acordo de Serviços da OMC), dispositivos sobre desenvolvimento, exceções e salvaguardas para balanço de pagamentos, e consultas e solução de controvérsias. 18

Além disso, i reconhecida na Declaração de Doha a necessidade de uma estrutura que assegure condições transparentes, estávcis e previsívcis para o investimento estrangeiro de longo-prazo. O texto da Declaração reconhece ainda a exigência de um apoio mais efetivo aos países em desenvolvimento e aos menos desenvolvidos, no que se refere à assistência técnica, análise de políticas e desenvolvimento, como forma de melhor avaliar as implicações de uma cooperação multilateral. Sugere o documento inclusive o trabalho em parceria com outras instituições, como a Conferência das Nações Unidas para o Comércio e Desenvolvimento - UNCTAD (Linited Nations Conference on Trade and Development), que possui como meta central o desenvolvimento dos países menos desenvolvidos.

Desse modo, a criação de um AGI, que tem por objetivo o estabelecimento de regras claras, gerais e definitivas sobre o tema investimentos, para todos os Estados-Membros da OMC, ${ }^{19}$ poderá oferecer grandes benefícios para os paises com maior potencial investidor, vez que a eles será proporcionada maior segurança no tratamento de seus investimentos no exterior. Mas tal acordo deverá também estar atento às necessidades dos países em desenvolvimento e de menor desenvolvimento relativo, devendo contemplar cláusulas que possibilitem o progresso de scus variados membros.

17. As Declarações são acordos internacionais que firmam principios juridicos para a Socicdade Internacional. Ver SILVA. Direito Internacional Público, p. 42.

18. OMC: Declaraçâao Ministerial de Doha, Parágrafo 22. Ver site www.wio.org.

19. Um levantamento da UNCTAD revela que. em 2000, o número de BITs (Bilateral Imeshnent Treaties) já chega a 1.400 , envolvendo cerca de 160 paises. A multiplicidade de acordos sobre o tema mostra a necessidade de se criar regras internacionais sobre o mesmo. Ver THORSTENSEN, Op. Cü p. 305. 
3. O Brasil e as negociaçõus da OMC sobre investimentos.

O Rrasil vem demonstrandu certa flexibilidade na negociação do tema investimentos na OMC. ${ }^{20}$ Por ser um grande receptor de investimentos estrangeiros diretos, propugna pelo estabelecimento, através de um Acordo Geral sobre Investimentos, de um quadro-base que delimite direitos e obrigações para os investidores e para os paises receptores de investimentos estrangeiros.

No que se refere à regra do tratamento nacional (não-discriminação), destaca o Brasil o papel de grande importância por ele desempenhado para a atração dos investimentos, por garantir previsibilidade para os investidores externos. Por outro lado, destaca yue a regra do tratamento nacional para investimentos é fundamentalmente diferente daquela para o comércio de bens. Desse modo, um Acordo Geral sobre Investimentos deve permitir exceções para ser viável. ${ }^{21}$ A Índia, por outro lado, não-concebe a consagração desta regra para investimentos, por temer as conseqüências negativas que ela pode gerar no controle do fluxo de investimentos por parte do Estado. 22

Saliente-se que esta posição não se coaduna com a de países como os EUA e a União Furopéia, que defendem a eliminação de todas as medidas discriminatórias para efeitos de liberalização, conferindo aos investidores altos padrões de proteção, tanto para as fases de pré-estabelecimento quanto para pósestabelecimento. Desse modo, não atentam para uma questão de fundamental relevância, que é o desenvolvimento, o que deverá ser tema de árdua negociação na $\mathrm{OMC}^{23}$

Ainda na perspectiva das exceções ao princípio do tratamento nacional, há a ıxceção da balança de pagamentos. Esta serve como instrumento para que os governos possam. em momentos de crise no equilíbrio da balança de pagamentos, deixar de cumprir determinados compromissos estabelecidos no âmbito da

20. MRE: Carta de Genebra. ano 1. v. 4, Maio de 2002. p. 12.

21. MRE: Carta de Genebra. ano I, v. 4, Maio de 2002. p. 12.

22. OMC: WT/WTGI/W/149.

23. Para análise do tema por meio de uma perspectiva desenvolvimentista, ver os documentos elaborados pela Índia para Grupo de Trabalho sobre Comércio e Investimentos da OMC: WT/WTGI/W/148 e WT/WTGI/W'150. 
regulamentação do comércio mundial. Através desse instituto, estarão os governos aptos a melhor estabelecer políticas o interesse público, restringindo a regra do tratamento nacional, segundo salientou o próprio Secretariado da OMC. ${ }^{24}$

Deve-se ressaltar que essas medidas não necessariamente atingem as regras de livre comércio, e mesmo que venham a atingir, são apenas exceções e de cunho bastante restrito. Assim, é de interesse do Brasil a extensão, bem como uma efetiva regulamentação, da lista de exceções ao princípio do tratamento nacional, com o intuito de melhor atender ao interesse nacional, principalmente em momentos de crise financeira.

A liberalização da transferência de fundos relativos a investimentos é vista com certa restrição pelos países em desenvolvimento, com destaque para o Brasil, visto que uma proteção irrestrita dos investimentos de portfólio pode ter conseqüências econômico-financeiras desastrosas para esses países. Isto porque esses investimentos podem ser vetores de crises especulativas nos mercados dos países em desenvolvimento, causando prejuizos incalculáveis, como as crises ocorridas no sudeste asiático em 1998 e a enfrentada pela Argentina e Brasil ao longo do ano de $2001 / 2002$.

Assim, é imperativo que cada país tenha a possibilidade de regulamentar os investimentos de portfólio da forma a melhor responder aos anseios e interesses nacionais, estando apto, inclusive, a restringir em certos momentos de crise a inversão deste capital. Ressalte-se que novamente há um conflito de interesses entre os paises desenvolvidos, que tendem a incluir entre os investimentos sujeitos à regulamentação os denominados de portfólio, ${ }^{25}$ e os países em desenvolvimento, que pretendem excluí-lo.

Os paises desenvolvidos pretendem ainda nas negociações de acordos de investimento, a redução ou eliminação dos requisitos de desempenho, assim como da transferência forçada de tecnologia. Todavia, é interessante destacar que a posição brasileira é avessa a esta idéia, por ser o Brasil um país em desenvolvimento, com interesse em promover uma efetiva transferência de tecnologia, reduzindo assim a distância que o separa dos países desenvolvidos. Desse modo, pretende estabelecer

24. Para um estudo mais aprofundado sobre a matéria no âmbito da $\mathrm{OMC}$, ver $\mathrm{OMC}$ : WT/WTGI/W/137, de 26.08.02.

25. Esta é a posição dos EUA, exposta na comunicação WT/WTGI/W/142 enviada ao Grupo de Trabalho sobre Comércio e Investimentos da OMC: 
cláusulas que viabilizem a transferência de tecnologia para a promoção do próprio desenvolvimento. Ressalte-se que por iniciativa do Brasil foi requerido ao Secretariado um estudo sobre a contribuição do investimento direto estrangeiro para a transferência de tecnologia para os países em desenvolvimento. ${ }^{26}$

Desse modo, para o Brasil, regras que contenham disposições sobre transferência de tecnologia e TRIMs que estejam em conformidade com o Acordo TRIMs são de salutar relevância, vez que podem orientar as políticas de desenvolvimento nacional, capazes de proporcionar a redução das desigualdades na esfera global.

No que se refere à criação de um mecanismo de solução de controvérsias para litígios sobre investimentos, saliente-se que os países desenvolvidos, ao se iniciarem as negociações sobre o AGI, pretenderão incluir procedimentos que coloquem investidor e Estado no mesmo nível hierárquico em uma disputa sobre investimentos. Porém, um possível mecanismo de solução de controvérsias que discipline as disputas investidor-Estado dessa forma, no âmbito da $\mathrm{OMC}^{27}$ não é uma idéia bem acolhida entre os mais diversos países em desenvolvimento, entre eles, o Brasil, que alegam ofensa ao princípio da soberania nacional.

Além disso, por serem os paises em desenvolvimento eminentemente receptores de investimento, com tal mecanismo acabariam por se posicionar de maneira frágil e vulnerável no cenário internacional, perdendo grande flexibilidade na adoção de políticas nacionais. ${ }^{28}$

Não foi por outro motivo que o Brasil ainda não ratificou os 14 Acordos Bilaterais de Investimento assinados com diversos países, além de não-fazer parte da

26. MRE: Carta de Genebra. ano 1, v. 7, Agosto de 2002. p. 9. Para um estudo mais detalhado sobre o tema investimentos estrangeiros diretos e transferência de tecnologia. ver OMC: WT/WGTV/W/136. de 16.08.02.

27. Para maiores detalhes accrca das discussões sobre o mecanismo de solução de controvérsias sobre investimentos na OMC, ver o documento OMC: WT/WTGI/W/134. de 07.08.02.

28. É interessante destacar que o mecanismo sobre solução de controvérsias do Acordo sobre Investimentos do Mercosul não prevê a possibilidade de uma demanda investidor-Estado a um Tribınal Arbitral, reportando-se para o Centro Internacional para Resolução de Conflitos Relativos a Investimentos (no âmbito do BIRD), a critério do Estado-Parte no conflito. Para o Acordo sobre Investimentos do Mercosul, ver o site: www. ftaa-alca.org. 
Convenção para a Resolução de Conflitos Relativos aos Investimentos, ${ }^{29}$ no seio do BIRD, que criou um Centro Internacional para Resolução de Conflitos Relativos a Investimentos (ICSID), podendo os investidores acionar diretamente o órgão, o qual chamará à lide o Estado demandado, proporcionando uma solução diplomática (através da conciliação) ou jurisdicional (tribunal de arbitragem). ${ }^{30}$

Assim, um AGI no âmbito da OMC deve observar tanto os interesses dos países desenvolvidos quanto dos países em desenvolvimento, sob pena de nãoproporcionar resultados satisfatórios para nenhum dos grupos de paises. Nesta esteira, foi proposto pelo Brasil que um o futuro AGI possua regras efetivas sobre desenvolvimento, e não somente declarações preambulares sem qualquer eficácia, pois maiores periodos de transição ou assistência técnica não seriam suficientes para se atingir o desenvolvimento almejado pelos paises menos desenvolvidos. ${ }^{31}$

4. O desenvolvimento e seus reflexos para a negociação do tema investimentos na OMC.

Os investimentos vêm ganhando cada ve $z$ mais espaço nas discussões acerca de seus efeitos para o comércio internacional, e, com isso, já desfrutam de papel de destaque na regulamentação estabelecida no âmbito da OMC. O Grupo de Trabalho sobre Comércio e Investimentos, que coordena as discussões sobre as normas que possivelmente farão parte de um AGI, já está estruturando as bases das futuras negociações sobre investimentos que se iniciarão a partir da V Conferência Ministerial em Cancún (México), em 2003.

Assim, o tema desenvolvimento vem ganhando relevante papel nessas discussões do Grupo de Trabalho, posto que a própria Declaração de Doha priorizou o tema como parte das negociações de um futuro Acordo Geral sobre Investimentos, tendo a Rodada de Doha, também, por isso, sido denominada "Rodada do Desenvolvimento" Desse modo, deve a referida negociação abarcar uma visão

29. Também denominada Convenção de Washington (1965).

30. NGUYEN \& PELLET, Direiro Internacional Público, p. 644.

31. MRE: Carla de Genebra ano 1, v. 7. Agosto de 2002. p. 10. 
advinda da "teoria do direito do desenvolvimento" 32 compreendendo esta a forma como os investimentos estrangeiros podem ser mais benéticos para os países receptores desses recursos, na busca de um maior equilíbrio econômico na esfera global.

Além disso, mister se faz ressaltar que os investimentos devem ser apreciados como um dos pilares do desenvolvimento. ${ }^{33}$ posto que são capazes de promover uma efetiva melhoria na qualidade de vida das populações dos paises receptores de investimento, através do aumento de receita, nível de empregos e modernização tecnológica. Conforme ressaltado, o documento WT/WTGI/W/149, elaborado pela Índia para o Grupo de Trabalho sobre Comércio e Investimentos da OMC. levanta justamente a questão do desenvolvimento nas negociações sobre investimentos.

Assim, um futuro AGl terá de acolher, durante as negociações, a inclusão de exceções (ao princípio do tratamento nacional) que priorizem o desenvolvimento. como, por exemplo. exceções gerais e exceções permanentes. ${ }^{34}$ Isto porque o livre comércio não é um fim em si mesmo, mas o instrumento para promover uma maior interrelação entre os países, na busca do bem comum.

Não conseguindo o AGI incluir referidas disposições acerca do desenvolvimento, não terá ele atingido uma de suas finalidades, podendo ser duramente rechaçado pelos paises de menor desenvolvimento. que necessitam da aplicação de políticas públicas de caráter nacional para melhor adequar os investimentos aos seus interesses. Segundo Rodrik. ${ }^{35}$ as estratégias de desenvolvimento devem estar amparadas por políticas públicas que vislumbrem as peculiaridades e o interesse nacional, o que somente poderá ocorrer se os EstadosMembros possuírem certa margem para estabelecer quais as políticas que atendam às condições e interesses locais.

32. GRANGER, R. Pour un Droit du Développement dans les pays sous-developpés. In: Dix Ans de Conférences d'agrégation - Études de Droit Commercial offertes à Hamel, 1961. Apud CARVAlhoSA, M. Direito Econômico. São Paulo: Revista dos Tribunais, 1973. pp. 244-246.

33. MOISÉS, Direito ao desenvolvimento e investimentos estrangeiros, p. 69.

34. BARRAL, O protecionismo e o neoproficionismo. p. 41.

35. Rodrik, Trading in illusions, p. 11. 
5. Conclusão.

('omo já dito, a negociação de instrumentos legais, no âmbito da $\mathrm{OMC}$, que regulem os investimentos internacionais vêm ganhando papel de destaque, desde a Rodada Uruguai (1986-1994), que culminou com a aprovação do Acordo TRIMs. Este acordo iniciou o tratamento legal aos investimentos, inserindo as regras do tratamento nacional e da proibição das restrições quantitativas ao tratamento conferido aos investimentos.

Entretanto, foi durante a Conferência Ministerial de Singapura (1996) que surgiu a discussão sobre a viabilidade de implementação de um Acordo Geral sobre lnvestimentos, que abrangesse todos os Estados-Membros da OMC. Para estudar e propor sugestões a respeito desta nova regulamentação, foi criado um Grupo de Trabalho sobre Comércio e Investimentos.

Este Grupo de Trabalho ganhou novas atribuições após a Conferência Ministerial de Doha (2001), posto que ficou encarregado de estruturar as bases das futuras negociações sobre o AGI, discutindo temas como: alcance e definição do tema investimentos, transparência, não-discriminação, modalidades para préestabelecimento baseadas em listas positivas do tipo GATS (Acordo de Serviços da OMC), dispositivos sobre desenvolvimento, exceções e salvaguardas para balanço de pagamentos, e consultas e solução de controvérsias. ${ }^{36}$

É interessante ressaltar que em virtude da possibilidade de este tema ser inserido no single underlaking, já a partir do próximo ano, poderá o Brasil se utilizar deste ponto para exercer pressão sobre tópicos que favoreçam ao seu interesse neste acordo ou em outros temas, como a redução de subsidios e outras práticas distorcivas exercidas pelos países desenvolvidos (p. ex. a aplicação de medidas de salvaguarda e antidumping. de maneira ilegal).

No que se refere à liberalização da transferência de fundos relativos a investimentos, incluindo os investimentos de portfólio no AGI, como desejam os EUA e demais paises exportadores de capital volátil, tal medida é vista com restrição pelos paises em desenvolvimento, entre eles o Brasil. Para evitar efeitos negativos do livre fluxo de capitais, foi proposto, sobretudo pelos paises em desenvolvimento, um efetivo controle do fluxo internacional de capitais, através da imposição de regras e 
controles que preservassem a possibilidade de autodeterminar seu destino econômico. ${ }^{37}$

Quanto à redução dos requisitos de desempenho e transferência de tecnologia, verifica-se a existência de certa margem de negociação para o Brasil, posto que já existe um Acordo TRIMs que regula esta matéria. Além disso, a discussão sobre tal redução deve estar acompanhada de debates sobre temas como as práticas das transnacionais que afetam o comércio, como transferência de recursos via preços e as práticas comerciais restritivas, que também provocam efeitos restritivos c distorcivos ao comércio. Assim, a elaboração de um código de conduta para as empresas transnacionais, no moldes do elaborado pela extinta Comissão das Nações Unidas para Corporações Transnacionais (United Nations Commission on Transnational Corporations) deve fazer parte da discussão.

No que tange à instituição de procedimentos claros e transparentes para resolução de disputas de investimento, ela certamente deverá abranger os interesses dos Estados-membros. Assim. deverá o Brasil defender a criação de um mecanismo de solução de controvérsias para investimentos que seja transparente, mas que somente permita a demanda entre Estados, através do instituto da proteção diplomática, sob pena de colocar em questão a sua soberania. O próprio ('ongresso brasileiro é bastante reticente à possibilidade de demandas diretas dos investidores contra os Estados.

Além disso, ao se proceder desta forma, estar-se-ia criando uma situação mais favorável para o investidor estrangeiro em relação ao investidor nacional. posto que este deve obrigatoriamente se submeter à jurisdição nacional. enquanto aquele não estará obrigado a fazê-lo.

Conforme se verificou, as posições dos diversos países na negociação dos investimentos são bastante diversas, para não dizer antagônicas. Como as negociações sobre um Acordo Geral de Investimentos ainda não se iniciaram na OMC, é fundamental que o Brasil participe ativamente das discussões do Grupo de Trabalho sobre Comćrcio e Investimentos, que ora estão ocorrendo, para incluir nas bases de negociação as exceções e os seus interesses, que foram anteriormente apresentados.

37. SINGER, Perspectivas de Desenvolvimento da América Latina, p. 140. 
Por fim, deve-se ressaltar que a OMC é hoje um dos principais foros internacionais para discussão e entendimento entre os Estados. Não-basta promover uma visão restrita e míope da realidade internacional, mas utilizar o seu potencial para trazer maiores vantagens para todos os seus membros. Assim, as preocupações sobre desenvolvimento devem fazer parte das discussões sobre liberalização e proteção dos diversos temas, principalmente os investimentos. É nessa perspectiva que deve o Brasil se posicionar durante as negociações. principalmente por presidir o Grupo de Trabalho sobre Comércio e Investimentos, podendo cfetivamente consagrar normas que visem não-só ao seu interesse. mas ao de todos os países em desenvolvimento.

\section{Anexos.}

\section{Declaração Ministerial de Doha - Parágrafos 20-22 (Relação entre Comércio e Investimentos)}

20. Recognizing the case for a multilateral framework to secure transparent, stable and predictable conditions for long-term cross-border investment, particularly foreign direct investment, that will contribute to the expansion of trade, and the need for enhanced technical assistance and capacity-building in this area as referred to in paragraph 21, we agree that negotiations will take place after the Fifth Session of the Ministerial Conference on the basis of a decision to be taken, by explicit consensus, at that session on modalities of negotiations.

21 . We recognize the needs of developing and least-developed countries for enhanced support for technical assistance and capacity building in this area, including policy analysis and development so that they may better evaluate the implications of closer multilateral cooperation for their development policies and objectives. and human and institutional development. To this end, we shall work in cooperation with other relevant intergovernmental organisations, including UNCTAD, and through appropriate regional and bilateral channels, to provide strengthened and adequately resourced assistance to respond to these needs.

22. In the period until the Fifth Sessiun. further work in the Working Group on the Relationship Between Trade and Investment will focus on the clarification of: scope and definition; transparency; non-discrimination; modalities for pre-establishment commitments based on a (SATS-type, positive list approach; development provisions; exceptions and balance-of-payments safeguards; consultation and the settlement of 
disputes between members. Any framework should reflect in a balanced manner the interests of home and host countries, and take due account of the development policies and objectives of host governments as well as their right to regulate in the public interest. The special development, trade and financial needs of developing and least-developed countries should be taken into account as an integral part of any framework, which should enable members to undertake obligations and commitments commensurate with their individual needs and circumstances. Due regard should be paid to other relevant WTO provisions. Account should be taken, as appropriate, of existing bilateral and regional arrangements on investment.

São Paulo. abril de 2004.

\section{Bibliografia.}

BARRAL, W. O protecionismo e o neoprotecionismo. São Paulo: Aduaneiras, 2002. CHUDNOVSKY, D. Investimentos Externos no Mercosul. Campinas: Papirus Editora, 1999.

DUNNING, J. H. Multinational Enterprises and the Global Economy. Beccles: William Clowes Ltd., 1993.

DECRETO Presidencial n. 1.355, de 30.12.94 (Promulga a Ata Final que incorpora os resultados da Rodada Uruguai de Negociações Comerciais Multilaterais do GATT).

FONSECA, J. B. L. Direito Econômico. Rio de Janeiro: Forense. 1998.

GRANGER, R. Pour un Droit du Développement dans les pays sous-developpés. In: Dix Ans de Conférences d'agrégation - Études de Droit Commercial offertes à Hamel, 1961. Apud CARVALHOSA, M. Direito Econômico. São Paulo: Revista dos Tribunais. 1973. pp. 244-246.

JACKSON, J. H. The Jurisprudence of GATT und the WTO: Insights on treaty law und economic relations. Cambridge: Cambridge University Press, 2002.

KRUGMAN. P R.: OBSTFELD, M. Economia Internacional: Teoria e Política (trad. Celina Laranjeira). 5. ed. São Paulo: Makron Books, 2001.

Ministério das Relações Exteriores da República Federativa do Brasil. Carta de Genehra. Ano 1, v. 4, Maio de 2002. 
Ministério das Relações Exteriores da República Federativa do Brasil. Curta de Genebra. Ano 1, v. 7. Agosto de 2002.

MOISÉS. C. P. Direito ao desenvolvimento e investimentos estrangeiros. São Paulo: Editora Oliveira Mendes, 1998.

NGUYEN, O., PELleT, A. Direito Internacional Público. 4. ed. Lisboa: Calouste Gulbenkian, 1992.

RAINELLI, M. A Organização Mundial do Comércio. Lisboa: Terramar, 1996.

RODRIK, D. Trading in illusions. Foreign Policy Magazine. Washington, Carnegie Fndowment for International Peace, April/May 2001.

SINGER, P Perspectivas de Desenvolvimento da América Latina. Revista Lua Nova. São Paulo: Centro de Estudos de Cultura Contemporânea, 1996.

SILVA, R. L. Direito Internacional Público. 2. ed. Belo Horizonte: Del Rey, 2002.

TROYANO, F A. Medidas de investimento relacionadas ao comércio. In: CASELLA, P. B. e MERCADANTE, A. A. (Orgs.). Guerra Comercial ou integração mundial pelo comércio?: a OMC e o Brasil. São Paulo: Editora LTr, 1998.

THORSTENSEN, V. OMC ... Organização Mundial do Comércio: As regras do comércio internacional e a nova rodada de negociações multilaterais. 2. ed. São Paulo: Aduaneiras, 2001.

United Nations Conference on Trade and Development. World Investment Report: Transnational Corporations and Export Competitiveness. 2002.

World Trade Organization. Ministerial Declaration. Doha, 2001. Ver site www.wto.org. . Documento WT/WGTI/W/134.

. Documento WT/WGTI/W/136.

. Documento WT/WGTI/W/137.

Documento WT/WGTI/W/142.

. Documento WT/WGTI/W/149.

WTO: "Beyond the agreements: investment, competition, procurement, simples procedures". Disponivel em: http://www.wto.org. Acesso em 07 ago. 2002. 